\title{
Acute Systemic Toxicity Of Four Mimosaceous Plants Leaves In Mice
}

\author{
Syed Muzammil Ahmed ${ }^{1}$, Salman Ahmed ${ }^{2}$, Farhana Tasleem³ ${ }^{3}$ \\ Muhammad Mohtasheem ul Hasan ${ }^{4}$, Iqbal Azhar ${ }^{5}$ \\ ${ }^{1-5}$ (Department of Pharmacognosy, Faculty of Pharmacy, University of Karachi, Karachi - 75270, Pakistan)
}

\begin{abstract}
Nature provides drugs in the form of medicinal plants to cure all ailments of mankind with fewer side effects. These medicinal plants can cause some serious damaging effects on the vital organs of the body too; there is a need of toxicity studies to provide their safe use both in human and animals. The present study reports the acute systemic toxicity of methanolic extracts of leaves of Adenanthera pavonina L., Peltophorum roxburghii Deneger., Prosopis cineraria Druce and Prosopis juliflora DC., (Mimosaceae) in swiss albino mice to explore their suitable doses for pharmacological screening. Observations were made immediately and after 1/2,1, 4, 24 and 48hours of intraperitoneal drug administration. Adenanthera pavonina extract at the dose of $150 \mathrm{mg} / \mathrm{kg}$ body weight is considered to be safe. Whereas remaining extracts of investigated plants are relatively safe at the dose of $100 \mathrm{mg} / \mathrm{kg}$ body weight.
\end{abstract}

Keywords - Acute systematic toxicity, Adenanthera pavonina, Methanol extract, Mimosaceae, Peltophorum roxburghii, Prosopis cineraria, Prosopis juliflora, Swiss albino mice.

\section{INTRODUCTION}

Herbal drugs are playing an important role in health care all over the world, especially in developing countries because they are being cheap, locally available and consider being safe. Medicinal plants behave as authentic medicines because of bioactive chemical compounds. The natural origin may not signify that they are safe. Limited evidence suggests that herbal drugs associated adverse effects are less. Determination of efficacy and safety of herbal remedies are necessary because of their self medication[1]. Although there is a limited data available about the pharmacology and toxicology for the most commonly used herbal remedies[2]. Therefore, efforts to elucidate health benefits and risks of herbal medicines should be intensified.

Adenanthera pavonina L., Peltophorum roxburghii Degener., Prosopis cineraria Druce and Prosopis juliflora DC are medicinal plants of Pakistan and India belong to the family Mimosaceae[3]. Adenanthera pavonina L., leaves decoction is used in blood pressure, cholera, general paralysis[4], gastric complaints (diarrhoea and dysentery)[5], gout and rheumatism[6]. Chemical literature survey of Adenanthera pavonina revealed the presence of triterpenes[7], flavonoids[8] and fatty acids[9]. Acute oral toxicity study of the ethanolic extract of leaves revealed $5 \mathrm{~g} / \mathrm{kg}$ as nontoxic dose[10]. The bark of Peltophorum roxburghii Degener is used in dysentery, toothache, pains and sores[11]. The hexane and methanol extracts of plant showed anti microbial activity[12]. Prosopis cineraria Druce leaves are used in cataract, dyspepsia, earache and toothache[13]. Literature survey of $P$. cineraria revealed the presence of alkaloids[14], fatty acids[15], glycosides and sterols[16]. The acute and sub acute oral toxicity of the methanol extract of leaves suggest $2 \mathrm{~g} / \mathrm{kg}$ as safe dose[17]. Leaf preparations of Prosopis juliflora DC are used in dyspepsia, earache, mouth infections, scorpion stings, snake bites[18], bronchitis, dermatitis, parasitic infections and urinary disorders[19]. The leaves of Prosopis juliflora contained amino acids, flavonoids[20], alkaloids and diketones[21]. The flavonol glycosides and hydroxycinnamic acid from Prosopis juliflora pollen are reported to possess antioxidant with high free radical scavenging activity [22].

The purpose of the present study is to investigate acute systemic toxicity of the methanol extracts (leaves) of four Mimosaceous plants (Adenanthera pavonina L., Peltophorum roxburghii Degener., Prosopis cineraria Druce and Prosopis juliflora DC ) in swiss albino mice in order to establish their safe doses for systemic use.

\section{MATERIALS AND METHODS}

2.1. Plant material: Leaves of Adenanthera pavonina L., Peltophorum roxburghii Degener., Prosopis cineraria Druce, and Prosopis juliflora DC were collected in summer 2011 from University of Karachi and deposited in the herbarium of department for reference.

2.2. Extraction: Leaves of Adenanthera pavonina L., Peltophorum roxburghii Degener., Prosopis cineraria Druce, and Prosopis juliflora DC., were dried under shade and soaked in methanol for a week. The extracts were filtered separately then concentrated using rotary evaporator at $40^{\circ} \mathrm{C}$. 
2.3. Animals: Swiss albino mice of both sexes (17-23g) were purchased from Aga Khan University and Hospital animal house. All animals were kept under laboratory conditions of room temperature with 12/12h light and dark cycles. They were allowed to free access to food and water ad libitum. The animals were divided into drug treated as test group and DMSO treated as control groups of six mice $(n=6)$ per cage for a minimum of three days prior to toxicity assessment. The groups of animals were transferred in different cages and marked with their identification.

2.4. Materials: Disposable syringes $1 \mathrm{ml}, 0.2 \mu$ membrane filters, filtration assembly, methanol, DMSO.

2.5. Preparation of Test Sample and Blank / Control Solution: The methanol extracts (100,150 and 200mg/kg body weight) of all investigated plants were solubilized in $0.5 \mathrm{ml}$ DMSO. Before injection the solution was passed through $0.2 \mu$ membrane filter. Each extract was agitated vigorously prior to withdrawal of injection doses to ensure even distribution of the extract. These extracts were administered intraperitoneally to the test group whereas control receiving only vehicle (DMSO).

2.6. Acute systemic toxicity studies: The acute systemic toxicity test of the methanol extract of leaves were carried out by the method described by Lorke [23] and modified by Vongtau et al [24]. Mice were treated intraperitoneally (i.p.) at the doses of 100,150 and $200 \mathrm{mg} / \mathrm{Kg}$ and were observed for biological reactivity continuously for the first 4 hour, then the number of survivors was noted after 24 and 48 hours of dosing. The protocol of the study is given in Table 1 . The $\mathrm{LD}_{50}$ was calculated by using following formula [25].

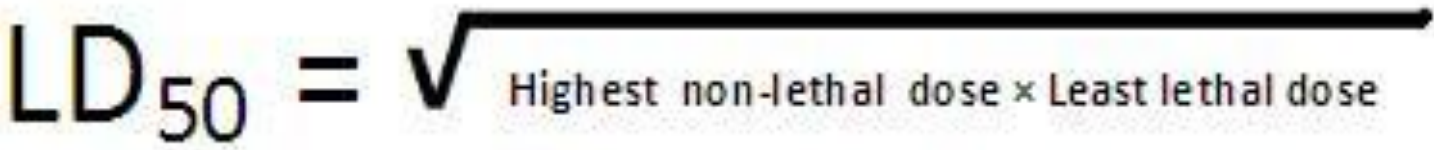

Table 1: Study Protocol of Acute Systemic Toxicity of Mimosaceous plants.

\begin{tabular}{|l|l|}
\hline Name of study & Acute systematic toxicity of Mimosaceous plants \\
\hline Test materials & $\begin{array}{l}\text { Methanolic extract of Adenanthera pavonina, Peltophorum roxburghii , Prosopis } \\
\text { cineraria, Prosopis juliflora., leaves. }\end{array}$ \\
\hline Details of animals used & Healthy swiss albino mice (03 Female and 03 Male) \\
\hline $\begin{array}{l}\text { Route of test drug } \\
\text { administration }\end{array}$ & Intraperitoneal administration with the help of disposable syringes \\
\hline $\begin{array}{l}\text { Dose of drug } \\
\text { administration }\end{array}$ & $0.5 \mathrm{ml} / 20 \mathrm{gm}$ of the mice body weight intraperitoneally \\
\hline Study duration & Acclimatization for 3 days and 48 hours study period \\
\hline Parameters observed & $\begin{array}{l}\text { Mortality, sign of illness, injury, pain distress, allergic reactions, changes of outer } \\
\text { appearance , difficulty in breathing, paralytic effect on hind limbs, behavioral alterations } \\
\text { (i.e., ataxia, hypoactivity, hyperactivity) and sedation }\end{array}$ \\
\hline
\end{tabular}

\section{RESULTS AND DISCUSSION}

After the intraperitoneal administration of $100 \mathrm{mg} / \mathrm{kg}$ dose of Adenanthera pavonina L., Peltophorum roxburghii Degener., Prosopis cineraria Druce, and Prosopis juliflora DC., no adverse reactions were seen for 48 hours so, all studied extracts at the same dose considered to be safe as they give normal activity. Where as $150 \mathrm{mg} / \mathrm{kg}$ i.p. considered to be safe only for the extract of Adenanthera pavonina and remaining three plant extracts are being considered toxic as they cause $100 \%$ mortality of mice till 48 hours. The $200 \mathrm{mg} / \mathrm{kg}$ i.p. of all studied extracts considers being toxic (Table 2). The final median lethal dose $\left(\mathrm{LD}_{50}\right)$ value was calculated by recorded 0 and $100 \%$ survival as the square root of the product of the lowest lethal dose and highest non-lethal dose[25]. The calculated $\mathrm{LD}_{50}$ for Adenanthera pavonina was to be $141.42 \mathrm{mg} / \mathrm{kg}$ body weight where as for Peltophorum roxburghii Degener., Prosopis cineraria Druce, and Prosopis juliflora DC., was. $122.47 \mathrm{mg} / \mathrm{kg}$ body weight. 
Table 2: Acute Systemic Toxicity of the leaves extracts of Mimosaceous plants.

\begin{tabular}{|c|c|c|c|c|c|c|c|c|}
\hline \multirow[t]{3}{*}{ TREATMENT } & \multirow{3}{*}{$\begin{array}{l}\text { DOSES } \\
\text { (mg/kg } \\
\text { body } \\
\text { weight) } \\
\end{array}$} & \multicolumn{6}{|c|}{ OBSERVATIONS } & \multirow{3}{*}{$\underset{\%}{\text { MORTALIY }}$} \\
\hline & & \multirow{2}{*}{$\begin{array}{l}\text { INJECTION } \\
\text { IMMEDIATELY }\end{array}$} & \multicolumn{5}{|c|}{ AFTER } & \\
\hline & & & $1 / 2 \mathbf{h r}$ & 1hr & 4hrs & 24hrs & 48hrs & \\
\hline $\begin{array}{l}\text { DMSO } \\
\text { (Control) }\end{array}$ & ----- & Normal activity & $\begin{array}{l}\text { Normal } \\
\text { activity }\end{array}$ & $\begin{array}{l}\text { Normal } \\
\text { activity }\end{array}$ & $\begin{array}{l}\text { Normal } \\
\text { activity }\end{array}$ & $\begin{array}{l}\text { Normal } \\
\text { activity }\end{array}$ & $\begin{array}{l}\text { Normal } \\
\text { activity }\end{array}$ & ---- \\
\hline \multirow{3}{*}{$\begin{array}{l}\text { Adenanthera } \\
\text { pavonina }\end{array}$} & 100 & Normal activity & $\begin{array}{l}\text { Normal } \\
\text { activity }\end{array}$ & $\begin{array}{l}\text { Normal } \\
\text { activity }\end{array}$ & $\begin{array}{l}\text { Normal } \\
\text { activity }\end{array}$ & $\begin{array}{l}\text { Normal } \\
\text { activity }\end{array}$ & $\begin{array}{l}\text { Normal } \\
\text { activity }\end{array}$ & 0 \\
\hline & 150 & Normal activity & $\begin{array}{l}\text { Normal } \\
\text { activity }\end{array}$ & $\begin{array}{l}\text { Normal } \\
\text { activity }\end{array}$ & $\begin{array}{l}\text { Normal } \\
\text { activity }\end{array}$ & $\begin{array}{l}\text { Normal } \\
\text { activity }\end{array}$ & $\begin{array}{l}\text { Normal } \\
\text { activity }\end{array}$ & 0 \\
\hline & 200 & $\begin{array}{l}\text { Breathing } \\
\text { problem }\end{array}$ & $\begin{array}{l}\text { Breathing } \\
\text { problem }\end{array}$ & $\begin{array}{c}\text { Paralytic } \\
\text { effect }\end{array}$ & $\begin{array}{c}\text { No } \\
\text { movement }\end{array}$ & Died & ---- & 100 \\
\hline \multirow{3}{*}{$\begin{array}{l}\text { Peltophorum } \\
\text { roxburghii }\end{array}$} & 100 & Normal activity & $\begin{array}{l}\text { Normal } \\
\text { activity }\end{array}$ & $\begin{array}{l}\text { Normal } \\
\text { activity }\end{array}$ & $\begin{array}{l}\text { Normal } \\
\text { activity }\end{array}$ & $\begin{array}{l}\text { Normal } \\
\text { activity }\end{array}$ & $\begin{array}{l}\text { Normal } \\
\text { activity }\end{array}$ & 0 \\
\hline & 150 & Lose of senses & $\begin{array}{l}\text { Paralytic } \\
\text { effect on } \\
\text { hind limbs }\end{array}$ & $\begin{array}{l}\text { Paralytic } \\
\text { effect on } \\
\text { hind } \\
\text { limbs }\end{array}$ & $\begin{array}{c}03 \text { mice were } \\
\text { died while } \\
\text { remaining } 03 \\
\text { were survived }\end{array}$ & Died & ---- & 100 \\
\hline & 200 & $\begin{array}{l}\text { Breathing } \\
\text { problem }\end{array}$ & $\begin{array}{c}\text { Breathing } \\
\text { problem }\end{array}$ & $\begin{array}{l}\text { Paralytic } \\
\text { effect } \\
\text { with hair } \\
\text { erection }\end{array}$ & Died & ---- & ---- & 100 \\
\hline \multirow{3}{*}{$\begin{array}{l}\text { Prosopis } \\
\text { cineraria }\end{array}$} & 100 & Normal activity & $\begin{array}{l}\text { Normal } \\
\text { activity }\end{array}$ & $\begin{array}{l}\text { Normal } \\
\text { activity }\end{array}$ & $\begin{array}{l}\text { Normal } \\
\text { activity }\end{array}$ & $\begin{array}{l}\text { Normal } \\
\text { activity }\end{array}$ & $\begin{array}{l}\text { Normal } \\
\text { activity }\end{array}$ & 0 \\
\hline & 150 & Lose of senses & $\begin{array}{l}\text { Paralytic } \\
\text { effect on } \\
\text { hind limbs }\end{array}$ & $\begin{array}{c}\text { Paralytic } \\
\text { effect on } \\
\text { hind } \\
\text { limbs }\end{array}$ & $\begin{array}{c}03 \text { mice were } \\
\text { died while } \\
\text { remaining } 03 \\
\text { were survived }\end{array}$ & Died & ---- & 100 \\
\hline & 200 & $\begin{array}{l}\text { Breathing } \\
\text { problem }\end{array}$ & $\begin{array}{c}\text { Breathing } \\
\text { problem }\end{array}$ & $\begin{array}{c}\text { Paralytic } \\
\text { effect } \\
\text { with hair } \\
\text { erection }\end{array}$ & Died & ---- & ---- & 100 \\
\hline \multirow{3}{*}{$\begin{array}{l}\text { Prosopis } \\
\text { juliflora }\end{array}$} & 100 & Normal activity & $\begin{array}{l}\text { Normal } \\
\text { activity }\end{array}$ & $\begin{array}{l}\text { Normal } \\
\text { activity }\end{array}$ & $\begin{array}{l}\text { Normal } \\
\text { activity }\end{array}$ & $\begin{array}{l}\text { Normal } \\
\text { activity }\end{array}$ & $\begin{array}{l}\text { Normal } \\
\text { activity }\end{array}$ & 0 \\
\hline & 150 & Normal activity & $\begin{array}{l}\text { Paralytic } \\
\text { effect on } \\
\text { hind limbs }\end{array}$ & $\begin{array}{l}\text { Paralytic } \\
\text { effect on } \\
\text { hind } \\
\text { limbs } \\
\end{array}$ & $\begin{array}{c}03 \text { mice were } \\
\text { died while } \\
\text { remaining } 03 \\
\text { were survived }\end{array}$ & Died & ---- & 100 \\
\hline & 200 & $\begin{array}{l}\text { Breathing } \\
\text { problem }\end{array}$ & $\begin{array}{c}\text { Breathing } \\
\text { problem }\end{array}$ & $\begin{array}{c}\text { Paralytic } \\
\text { effect } \\
\text { with hair } \\
\text { erection }\end{array}$ & Died & ---- & ---- & 100 \\
\hline
\end{tabular}

Plants and their derivatives played a key role in world health and have long been known to possess biological activity[26]. The importance of biological, chemical and pharmacological evaluations of plants derived agents used in the treatment of human ailments has been increasingly recognized in the last decades[27]. The data of the acute, subchronic and chronic toxicity studies (oral and systemic) on medicinal plants or preparations derived from them should be obtained in order to increase the confidence in its safety to human, particularly for use in the development of pharmaceuticals. The calculated $\mathrm{LD}_{50}$ values for investigated Mimosaceous plants may suggest the suitable and safe dose for biological studies using systemic route. 


\section{CONCLUSION}

It can be concluded that the methanol extracts of investigated Mimosaceous plants is relatively safe at $100 \mathrm{mg} / \mathrm{kg}$ body weight intraperitoneally. Further toxicity studies using different animal species recommended to elucidate the exact mechanism and loci of the fatal action of the extracts are necessary.

\section{REFERENCES}

1. L. Rodriguez-Fragoso, J. Reyes-Esparza, S.W. Burchiel, D. Herrera-Ruiz and E. Torres, Risks and benefits of commonly used herbal medicines in Mexico, Toxicology and Applied Pharmacology, 227(1), 2008, 125135.

2. A. Gurib-Fakim, Medicinal plants: traditions of yesterday and drugs of tomorrow, Molecular Aspects of Medicine, 27, 2006,1-93.

3. $\quad$ SI. Ali. Flora of West Pakistan, No.36 (Eds., E. Nasir and S.I. Ali), (Department of Botany: University of Karachi: Karachi, 1972).

4. C. Asima and C.P. Satyesh, editors. The treatise on Indian medicinal plants.Vol.2, (New Delhi: Publications and Information Directorate, 1992).

5. D.K. Holdsworth. Medicinal Plants of Papua New Guinea, South Pacific Commission Technical paper No.175, (Noumea: New Caledonia, 1977).

6. H.M. Burkill. The useful plants of West Tropical Africa. Vol. 2. (Royal Botanical Gardens: Kew, 1994).

7. N. Yadav, G. Misra and S.K. Nigam. Triterpenoids of Adenathera pavonina bark. Planta Medica, 29(2), 1976, 176-178.

8. A.M. Gennaro and G. Nasini. Flavonoids from Adenanthera pavonina. Phytochemistry, 11(4), 1972, 1515.

9. S. Sotheeswaran, M.R. Sharif, R.A. Mureau and G.J. Piazza. Lipids from the seven Fijian plant species, Food Chemistry, 49, 1994, 11-13.

10. C. Mayuren and R. Ilavarasan, Anti-inflammatory activity of ethanolic leaf extracts from Adenanthera pavonina (L) in Rats, Journal of Young Pharmacists, 1(2), 2009, 125-128.

11. R.C. Jagessar, A. Mohamed and G. Gomes, Antibacterial and antifungal activity of leaf extracts of Luffa operculata, vs Peltophorum pterocarpum, against Candida albicans, Staphylococcus aureus and Escherichia coli. Nature and Science 5(4), 2007, 81-93.

12. D. Veeramuthu, A. Muniappan and I. Savarimuthu, Antimicrobial activity of some ethnomedicinal plants used by Paliyar tribe from Tamil Nadu, India. Entomology Research Institute, Loyola College, India. BMC Complementary and Alternative Medicine, 6, 2006, 35.

13. A.Shahina, Ghazanfar and A.M.A. Al-Sabahi, Medicinal plants of Northern and central Oman (Arabia), Economic Botany 47(1), 1993, 89-98.

14. R.P. Rastogi and B.N. Mehrotra. Compendium of Indian Medicinal Plants: A CDRI Series. (Vol. IV) (Lucknow: Publication and Information Directorate, New Delhi, 1995).

15. S. Gangal, S. Sharma and A. Rauf, Fatty Acid Composition of Prosopis cineraria Seeds, Chemistry of Natural Compounds 45(5), 2009, 705 - 707.

16. H. Akhtar and O.P. Virmani, Dictionary of Indian Medicinal Plants. $\left(1^{\text {st }}\right.$ Ed) (Central Institute of Medicinal and Aromatic Plants: Lucknow, 1992).

17. M.P.M. Naina, V. Ravichandiran and M. Gobinath. Acute and Subacute Toxicity of Methanol Extract of Prosopis cineraria in Rats. Middle East Journal of Scientific Research, 7(6), 2011, 931-936.

18. N.M. Pasiecznik, P. Felker, P.J.C. Harris, L.N. Harsh, G. Cruz, J.C. Tewari, K. Cadoret and L.J. Maldonado. The Prosopis juliflora - Prosopis pallida Complex: A Monograph HDRA, Coventry, UK. 2001, p.172.

19. ICFRE (Indian Council Of Forestry Research And Education). Khejri (Prosopis cineraria), (ICFRE: Dehra Dun, India, 1993).

20. N.J. Carman. Systematic and ecological investigations in the genus Prosopis emphasising the natural products chemistry. Chemical Abstracts, 34, 1974, 4240.

21. R.G. Cates and D.F. Rhoades, Prosopis leaves as a source for insects. In: Mesquite, Its Biology in Two Desert Scrub Ecosystems. (Ed.) Simpson BB, Dowden, Hutchinson, Ross. (Stroudsburg: Pennsylvania, US, 1977) 61-83.

22. M.G. Campos, K.R. Markham and A. Proença da Cunha, Quality assessment of Bee- pollens using flavonoid/ phenolic profiles. Polyphenol Communications, 96, 1997, 53-54.

23. D. Lorke, A New Approach to Practical Acute Toxicity Testing, Archives of Toxicology, 54, 1983, 275287. 
24. H.O. Vongtau, S. Amos, L. Binda, D. Saidu, K.S. Gamaniel, O.F. Kunle, C. Wambebe, Pharmacological effects of the aqueous extract of Neorautanenia mitis in rodents, Journal of Ethnopharmacology, 72, 2000, 207-214.

25. F.N. Kalu, V.N. Ogugua, C.O. Ujowundu and C.R.K. Chinekeokwu, Chemical Composition and Acute Toxicity Studies on the Aqueous Extract of Combretum dolichopentalum Leaf in Swiss Albino Mice, Research Journal of Chemical Sciences, 1(8), 2011, 72-75.

26. M.M. Burns. Alternative medicine: Herbal preparation. Clinical Pediatric Emergency Medicine, 1, 2000, 186-190.

27. A.N. Dasture, Herbal Therapy. Ancient Science of Life, 21(4), 2002, 281-286. 